\title{
Effects of Light Environments on Leaf Traits and Phenotypic Plasticity of Canna indica
}

\author{
Yorianta Hidayat Sasaerila*, Sakinah Sakinah, Nita Noriko, Risa Swandari Wijihastuti
}

Department of Biology, Universitas Al Azhar Indonesia

*Corresponding Author: yshidayat@uai.ac.id

Submitted: 2021-05-07. Revised: 2021-05-23. Accepted: 2021-07-27

\begin{abstract}
Canna indica L (African arrowroot), is a beneficial, multi-use tropical perennial with a worldwide distribution, but relatively unexplored. This plant has the potential to be developed as a food crop in an intercropping system, utilizing idle land under commercial plantations such as rubber or teak. This study aimed to determine the best light-growing conditions for $C$. indica. A completely randomized design was used with growth light as the treatment consisting of $25 \%, 50 \%$, and $100 \%$ of natural light, respectively. Leaf traits, growth characteristics, and phenotypic plasticity were used to measure $C$. indica's response to different treatments. The results of this study showed that $C$. indica grown in low light has the best growth with increased height, leaf area, root and shoot dry weights, but decreased leaf thickness, which caused the increase in specific leaf area, leaf area ratio, and leaf weight ratio, but decreased root to shoot ratio. Based on leaf traits and biomass allocation, the phenotypic plasticity index was 0.23 , a typical number for shade tolerant species. These findings were the first time to be reported for $C$. indica. For agroforestry practices, it can be recommended that $C$. indica be used as an intercropping plant under tree canopies.
\end{abstract}

Key words: leaf traits; light environment; phenotypic plasticity; relative growth rate; shade tolerant

How to Cite: Sasaerila, Y. H., Sakinah, S., Noriko, N., \& Wijihastuti, R. S. (2021). Effects of Light Environments on Leaf Traits and Phenotypic Plasticity of Canna indica. Biosaintifika: Journal of Biology \& Biology Education, 13(2), 169-177.

DOI: http://dx.doi.org/10.15294/biosaintifika.v13i2.30175

\section{INTRODUCTION}

Canna indica (African arrowroot, Indian shot, Ganyong) is a multi-use tropical perennial species. All parts of this plant have commercial values, but they are still relatively unexplored. The rhizome is a good source of starch that can be consumed raw or boiled or can be processed to make noodles, pasta, or a variety of snacks. Its young leaves are eaten as a vegetable, the young seeds are used in the mixture of tortilla ingredients, and the stems and leaves are used for fodder (CABI, 2020). According to a report on the productivity of four Canna species including $C$. indica in Thailand, the four species tested were able to produce starch between 4.1-4.9 tonnes per ha (Piyachomkwan et al., 2002), indicating Canna's capacity as a flour producer. The development of $C$. indica to produce flour can help Indonesia to reduce its dependence on wheat imports, which have risen to over 10 million tonnes per year, equivalent to USD 2.8 million in 2019 (BPS, 2020).

Besides being an excellent source of carbohydrates and protein (Okonwu \& Ariaga, 2016), $C$. indica has also been reported to play an important role in soil conservation. Its large and fast-growing leaves help protect the soil from the rain, and are good materials for green manure due to its high content of macronutrients, and can be used to improve soil fertility (Moossa et al., 2015). For this reason, this plant is often planted on marginal soil to improve soil quality. $C$. indica is also used as phytoremediation plant to remove $\mathrm{Pb}, \mathrm{Zn}$, and $\mathrm{Cr}$, and via phytostabilization processes to remove $\mathrm{Ni}$ and $\mathrm{Cd}$ (Ediviani et al., 2018; Subhashini \& Swamy, 2014). Recently, Rudisirisak (2019) reported that $C$. indica is a good raw material for making paper.

There has been much research done on $C$. indica, covers a broad range of subjects such as its starch quality and physicochemical properties (Algar et al, 2019; Andrade-Mahecha et al., 2012), its bioactive components and phytochemical analysis (Al-Snafi, 2015; Ayusman et al., 2020; Ifandari et al., 2020), its organogenesis and ultrastructural features (Wafa et al., 2016), the effect of water deficiency and nutrients on its growth (Zhang et al., 2008), its floral vasculature and pollination biology (Glinos \& Cocucci, 2011; Miao et al., 2014), its use for domestic and industrial wastewater treatments (Subhashini \& Swamy, 2014), and its use for biogas production (Jiang et al, 2014). Unfortunately, little is known about $C$. indica's adaptability to different light environments (see for example Asmelash, 2017 and Ciciarelli, 2012). In fact, there are conflicting reports on $C$. indica's ability to tolerate shade (CABI, 2020; Plant for a Future, 2020).

Sunlight is one of the most significant environmental factors for plants as an immobile photoautotrophic organism, and the plant's ability to detect and convert light signals allows for successful adaptation and stress avoidance strategy (Schulze et 
al., 2019). This ability can be accessed through the analysis of leaf traits, biomass allocation, and phenotypic plasticity. The leaf traits reflect the correlation between plants and their environment, which influences their growth and strategy to survive. Leaf traits can be used to monitor the effects of biotic and abiotic environmental stresses on the plant. For example, a study on 12 herbaceous species showed that increases in Specific Leaf Area (SLA) and total leaf area were linked to low light conditions, and higher SLA correlates with higher leaf photosynthesis efficiency (Jagodziński et al., 2016). Plants' biomass allocation patterns to leaves, stems, and roots illustrate how they respond to various environmental conditions (Poorter et al., 2012), and plants use phenotypic plasticity to cope with environmental heterogeneity which has been reported to link to shade tolerance characteristics (Gianoli \& Valladares, 2012; Valladares et al., 2006).

In this paper, we report how different light environments affected $C$. indica's leaf traits, biomass allocation, and phenotypic characteristics. To our knowledge, no experiments have been conducted to study the effects of low light growing environment on the leaf traits, growth characteristics, and phenotypic plasticity of $C$. indica. If this plant were to be planted under thick tropical forest canopies or to produce a significant amount of starch, the efficiency of light capturing becomes the key factor of its survival and productivity. Plant breeding programs can also benefit from the knowledge on the plasticity of leaf and growth characteristics, as reported in Ipomoea batatas (Rahajeng et al., 2020). Besides, information on genetic plasticity could be exploited to develop a shade-tolerant cultivar of $C$. indica that can be planted as a food crop in agroforestry settings or under intact natural forest canopies, without deforestation. This study aimed to determine the best light-growing conditions for $C$. indica. This knowledge is essential in the effort to mass-produce this species as a food source.

\section{METHODS}

\section{Study area}

The experiment was conducted at the experimental field of the Biology Department, Universitas Al Azhar Indonesia, which is located in Kompleks Masjid Agung Al-Azhar Jl. Sisingamangaraja, Kebayoran Baru, Jakarta, Indonesia, $6^{\circ} 14^{\prime} \mathrm{S} 106^{\circ} 47^{\prime} \mathrm{E}$.

\section{Plant materials and field establishment}

Wild $C$. indica of white cultivar were planted from the rhizomes that originated in West Java, Indonesia and purchased from Trubus Store (http://tokotrubus.co.id). Indonesia has about 66 accessions of $C$. indica collected primarily from the island of Java (Sari et al., 2018). Based on this information, we sent samples of our plants used in this experiment to the Herbarium Bogoriense of the Indonesian Institute of Sciences, to confirm that they were Canna indica $\mathrm{L}$. The rhizomes were cut into three to five-cm-long pieces, each with a growing nodal point and was planted in soil in a polybag (10 $\mathrm{cm}$ in diameter), one cut of rhizome per polybag. The type of soil was silty clay loam with a $\mathrm{pH}$ of 6.9. The newly planted rhizomes were placed in a shaded nursery area, watered daily in the morning for one month after which the watering was terminated. Two weeks after being planted and stored in the nursery area, pots of growing $C$. indica were randomly selected and placed in separate but adjacent $2 \times 2 \mathrm{~m}$ treatment plots. There were no fertilizers used in this experiment.

Each plot was exposed to different light treatments: Full sun (100\% of natural light), moderate shade (50\% of natural light), and deep shade ( $25 \%$ of natural light). The different light environments were created by erecting four wooden poles $(1.5 \mathrm{~m}$ tall, 2.5 $\mathrm{cm}$ in diameter) on the four corners of each plot, and covering the top and all four sides with shading nets; one layer for moderate shade treatment and two layers for deep shade treatment (Figure 1A and 1B). The individual plots looked like flat roof huts. For the full sun treatment, the four poles were erected, but without shading net above and/or around it (Figure 1C). To obtain the percentage of the light reaching the plants in each treatment, the light intensity was measured at five different points, above and below the nets. The ratios of these measurements were the percentages of the light received by plants in each treatment: 50\% light (moderate shade) and 25\% light (deep shade) of full natural sunlight.

\section{Experimental set-up and measurement}

This experiment was set up with three light treatments and three replicates. All growth measurements were destructive and done at the end of the experiment, six months after the plants were planted. To measure the growth components, plants were randomly selected from each treatment and measured for the following growth components: plant dry weights, and plant height (the vertical distance from the meeting point between stem and root to the highest portion of the plant). Plants were harvested at the same age and size to remove the likelihood of an ontogenetic factor in the variations between light treatments (Poorter et al., 2012; Valladares et al., 2000). 


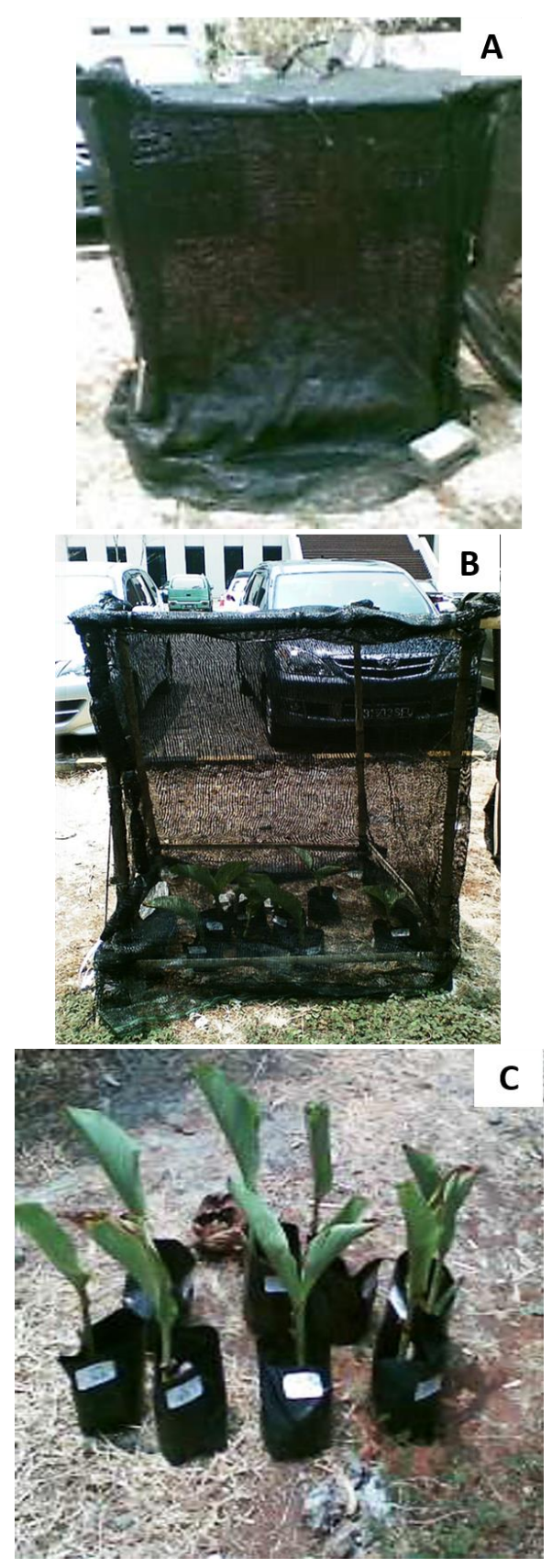

Figure 1. Canna indica grown under three light environments: A. Deep Shade (25\% of natural light); B. Moderate Shade (50\% of natural light); and C. Full sun (100\% of natural light).

Before measuring, plants from each treatment were taken out from the polybags and carefully cleaned to remove the soil from the rhizomes. The plants were then separated into leaves, stems, and rhizomes, and dried to a constant weight at $80^{\circ} \mathrm{C}$ to obtain the dry weights. The leaf area was measured using millimeter block paper as described by Pandey \& Singh (2011). The SLA (Specific Leaf Area, the ratio of leaf area to leaf dry mass expressed in $\mathrm{cm}^{2} \mathrm{~g}^{-}$ ${ }^{1}$ ), LWR (Leaf Weight Ratio, the ratio of leaf weight to plant weight expressed in $g$ leaf $g$ plant $^{-1}$ ), LAR (
Leaf Area Ratio, the ratio of leaf area to plant weight expressed in $\mathrm{cm}^{2} \mathrm{~g}^{-1}$ ), NAR ( Net Assimilation Rate expressed in $\mathrm{g} . \mathrm{cm}^{-2}$.day ${ }^{-1}$ ) and the RGR (Relative Growth Rate expressed in g.g ${ }^{1} \cdot$ day $^{-1}$ ) were calculated as described by Hunt (1990).

Phenotypic plasticity - a genotype's ability to exhibit different phenotypes under different environmental conditions (Gianoli \& Valladares, 2012) - was calculated for each component: the difference between the minimum and maximum mean values among the three treatments was divided by the maximum mean value. The phenotypic plasticity index is ranging from zero to one, as determined by Valladares et al. (2000).

\section{Statistical analyses}

The effects of different light growing environments on these measured parameters were tested using One-way ANOVA with SPSS 20.0, and the least significant difference (LSD) test was used to determine the statistical significance among the three light treatments. The statistical significance for all analyses was set at $\mathrm{p}<0.05$.

\section{RESULTS AND DISCUSSION}

The maximum and minimum air temperatures during this experiment were $30^{\circ} \mathrm{C}$ and $25^{\circ} \mathrm{C}$ respectively, with an average air temperature of $27 \pm 0.5^{\circ} \mathrm{C}$. The average relative humidity was $74 \pm 2.3 \%$ and the total precipitation was $984 \mathrm{~mm}$. The climate data were taken from the Badan Pusat Statistik (BPS, 2017).

\section{Leaf traits and growth characteristics}

The light environment significantly affected the leaf traits and growth characteristics of $C$. indica (Figure 2). The $C$. indica that grew under deep shade treatment (25\% natural light) produced significantly higher plant height $(\mathrm{F}=342.12 ; \mathrm{p}<0.001)$, leaf area $(\mathrm{F}=631.95 ; \mathrm{p}<0.001)$, and number of stomata $(\mathrm{F}=35011 ;<0.001)$ than the $C$. indica grown under full sun (100\% natural lights) (Table 1). Deep shadegrown $C$. indica had 30\%, 47\%, 39\%, and $74 \%$ higher plant height, leaf area, adaxial and abaxial stomatal densities, respectively, than full sun-grown $C$. indica. However, full sun-grown $C$. indica produced significantly thicker leaves $(\mathrm{F}=30.86$; $\mathrm{p}<0.001)$ than those grown under moderate shade and deep shade treatments. The leaf of full sun-grown $C$. indica was $28 \%$ thicker than those of deep shadegrown plants (Table 1).

Canna indica responded to low light condition under deep shade treatment by producing significantly larger leaf area and reduced leaf thickness which led to a significant increase in SLA 
$(\mathrm{F}=9.20 ; \mathrm{p}<0.015)$, LAR $(\mathrm{F}=39.12 ; \mathrm{p}<0.001)$, and LWR $(\mathrm{F}=5.81 ; \mathrm{p}<0.039)$ in $C$. indica grown in low light (deep shade treatment) compared to those grown in full sun treatment (Figure 3). The highest values of LAR, SLA, and LWR were observed in low light (deep shade) grown $C$. indica, and the lowest was in full sun-grown plants (Figure 3).

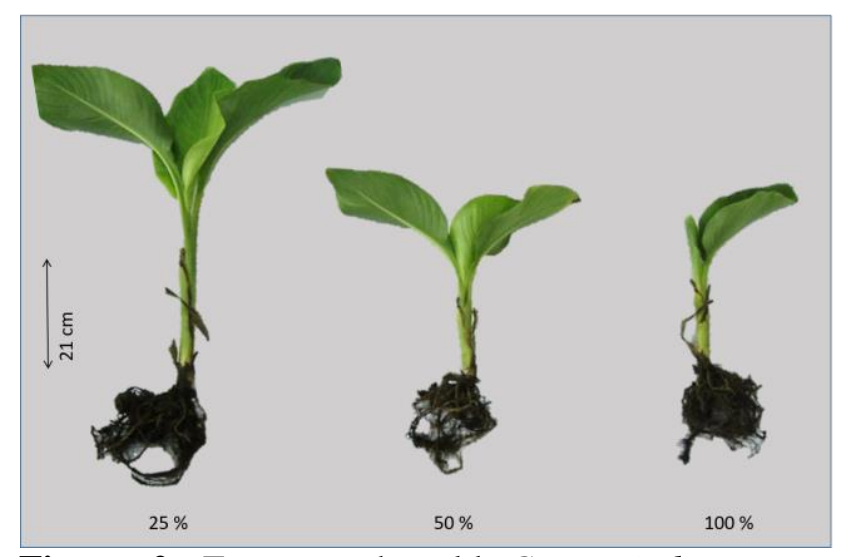

Figure 2. Four months old Canna indica grown under three light environments: A. Deep Shade (25\% of natural light); B. Moderate Shade (50\% of natural light); and C. Full sun (100\% of natural light). This experiment was done with three replications.

SLA is a ratio of plant leaf area to the dry weight of leaves, which means the higher the SLA, the greater the photosynthetic surface of the plant. LAR indicates the leafiness of a plant or the amount of leaf area produced per unit of biomass, and LWR is a measure of the plant's productive investment, as it addresses the relative expenditure on potentially photosynthesizing organs (Hunt, 1990). An increase in these three variables may indicate the primary adaptation of $C$. indica to the light growing conditions, as it has been reported in shade-tolerant species (Shipley, 2006; Wyka et al., 2012). The higher LAR, SLA, and LWR in $C$. indica grown under lower light conditions suggested that this species produced thinner but wider leaves, which have a lower mass than thicker leaves, as it has fewer cells per unit area. Thinner leaves are more efficient in capturing the light at low light availability levels, thus optimizing the use of carbon gain (Evans \& Poorter, 2001).

Table 1. Mean value \pm SE of leaf traits and growth components of five months old Canna indica, grown under three light conditions: Deep shade (25\% of natural light), Moderate shade (50\% of natural light), and full sun (100\% of natural light). Mean values with the same letters are not significantly different $(p<0.05, n=3)$

\begin{tabular}{|c|c|c|c|}
\hline \multirow{2}{*}{ Growth components } & \multicolumn{3}{|c|}{ Treatments } \\
\hline & Deep shade & Moderate shade & Full sun \\
\hline Plant height $(\mathrm{cm})$ & $55.1 \pm 4.8 \mathrm{a}$ & $49.7 \pm 2.5 \mathrm{ab}$ & $38.7 \pm 1.4 \mathrm{c}$ \\
\hline Leaf area $\left(\mathrm{cm}^{2}\right)$ & $67.71 \pm 16 \mathrm{a}$ & $45.74 \pm 13 b$ & $36.00 \pm 12 c$ \\
\hline Leaf thickness $(\mathrm{mm})$ & $0.18 \pm 0.019 \mathrm{c}$ & $0.21 \pm 0.017 \mathrm{~b}$ & $0.25 \pm 0.02 \mathrm{a}$ \\
\hline \multicolumn{4}{|c|}{ Stomatal densities (Total. $\mathrm{mm}^{-2}$ ) } \\
\hline - abaxial & $161.59 \pm 0.61 \mathrm{a}$ & $51.86 \pm 0.051 \mathrm{~b}$ & $41.08 \pm 0.068 \mathrm{c}$ \\
\hline - adaxial & $42.51 \pm 0.056 \mathrm{a}$ & $31.45 \pm 0.070 \mathrm{~b}$ & $26.09 \pm 0.011 \mathrm{c}$ \\
\hline Leaf weight $(\mathrm{g})$ & $2.32 \pm 0.10 \mathrm{a}$ & $1.66 \pm 0.05 b$ & $1.45 \pm 0.01 \mathrm{~b}$ \\
\hline Shoot weight (g) & $4.20 \pm 0.11 \mathrm{a}$ & $3.48 \pm 0.15 b$ & $2.71 \pm 0.06 \mathrm{c}$ \\
\hline Root weight (g) & $26.38 \pm 0.52 \mathrm{a}$ & $20.0 \pm 0.058 \mathrm{~b}$ & $20.74 \pm 0.97 b$ \\
\hline Root/Shoot weight (g) & $6.29 \pm 0.25 b$ & $5.77 \pm 0.39 b$ & $7.65 \pm 0.34 a$ \\
\hline RGR (mg.g ${ }^{-1} \cdot$ day $\left.^{-1}\right)$ & $0.105 \pm 0.0001 \mathrm{a}$ & $0.103 \pm 0.0001 b$ & $0.103 \pm 0.0001 b$ \\
\hline NAR $\left(\mathrm{mg} \cdot \mathrm{cm}^{-2} \cdot\right.$ day $\left.^{-1}\right)$ & $0.15 \pm 0.0002 c$ & $0.22 \pm 0.0004 b$ & $0.28 \pm 0.0011 \mathrm{a}$ \\
\hline
\end{tabular}

Note: RGR=Relative Growth Rate; NAR=Net Assimilation Rate

The optimal biomass partitioning principle, which states that plants assign more biomass to organs responsible for resource acquisition (McCarthy \& Enquist, 2007), may explain the high SLA, LAR, and LWR in low light as found in this experiment. It has been documented that high SLA values are associated with shaded leaves and may imply a lack of light (Neufeld \& Young, 2014; Wyka et al., 2012). Similar results were reported by Dwyer et al., (2014) where $30 \%$ of the 85 species investigated showed a significant positive correlation between high SLA and shade or lower light conditions. Moreover, Jagodziński et al., (2016) reported that three herbaceous species (Aegopodium podagraria, Asarum europaeum, and Galeobdolon luteum) reached their maximum SLA values after a significant decrease in light availability.

\section{Biomass allocation and phenotypic plasticity}

Canna indica's leaf dry weight showed a significant increase with a decrease in light growing conditions $(\mathrm{F}=47.47$; $(\mathrm{p}<0.001)$; Table 1$)$. The mean values of shoot and root dry weights of deep shadegrown $C$. indica were significantly higher than those of full sun-grown shoot dry weights $(\mathrm{F}=43.83$; $\mathrm{p}<0.001$; Table 1) and root dry weights $(\mathrm{F}=23.50$; 
$\mathrm{p}<0.001$; Table 1), respectively. Canna indica grew under moderate shade (50\% ambient light) exhibited intermediate growth characters between those grown in deep shade and full sun environment (Table 1).
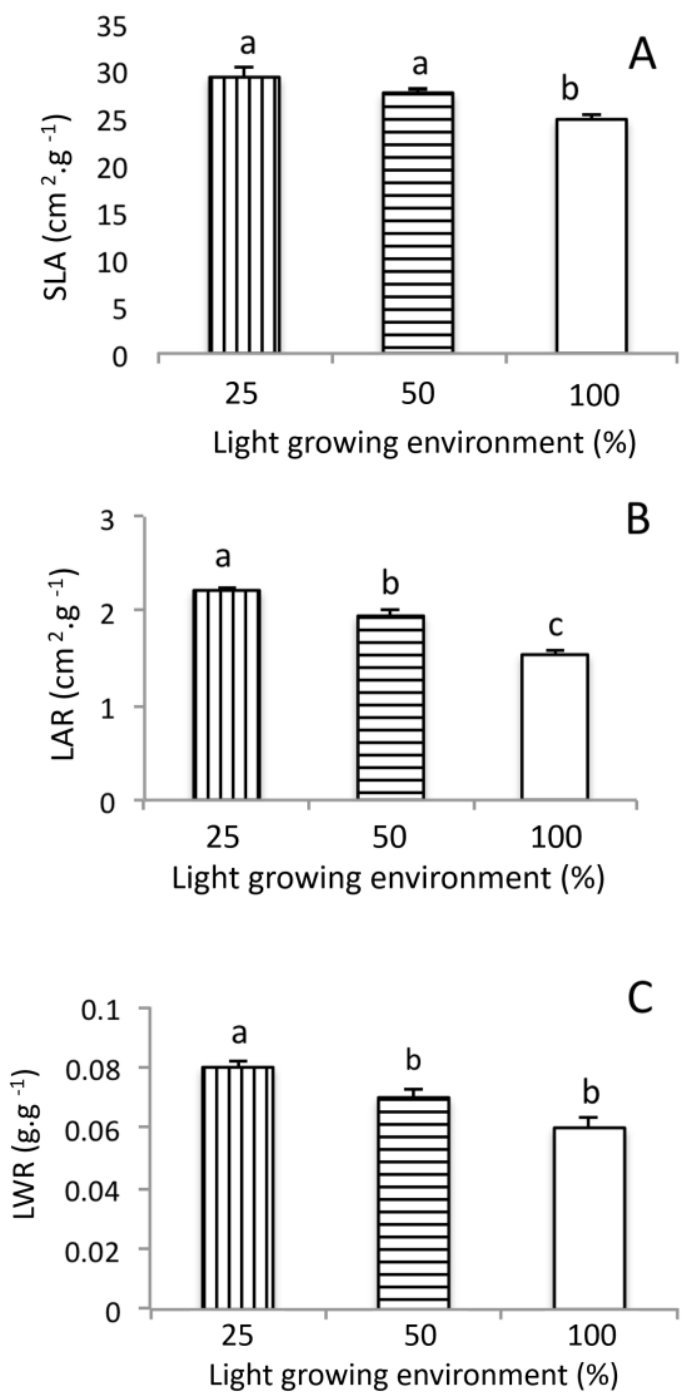

Note: SLA=Specific Leaf Area; LAR=Leaf Area Ratio; LWR=Leaf Weight Ratio

Figure 3. Leaf traits of Canna indica after 4 months grew under: deep shade (25\% of ambient light), moderate shade (50\% of ambient light), and full sun (100\% of ambient light) treatments. Mean values with the same letter are not significantly different $(p<0.05)$. (Mean $\pm S E, n=3$ ). (A: Specific Leaf Area (SLA), B: Leaf Area Ratio (LAR), C: Leaf Weight Ratio (LWR)).
Light environments had a significant effect on the growth and on the above and below ground biomass allocation of $C$. indica: RGR $(\mathrm{F}=27.55 ; \mathrm{p}<0.001)$, NAR $(\mathrm{F}=7342.44 ; \mathrm{p}<0.001)$ and root-shoot $(\mathrm{R} / \mathrm{S})$ ratio $(\mathrm{F}=8.57 ; \mathrm{p}<0.017)$. Full sun-grown $C$. indica had a higher R/S ratio and NAR, but lower RGR than both moderate shade- and deep shade-grown seedlings (Table 1). Morphological traits and biomass allocation were also strongly related to growth. RGR was positively correlated to $\mathrm{R} / \mathrm{S}$ ratio, and negatively correlated to LAR, LWR (except in $25 \%$ light treatment) and SWR (Stem Weight Ratio) (Table 2). These results showed $C$. indica's ability to adapt to various light growing environments.

The efficiency in the light-capturing ability of shaded grown plants may explain the faster growth of C. indica in a low light environment as indicated by higher RGR and lower NAR in this experiment. Deep shade-grown $C$. indica adapted low light conditions by increasing the allocation of carbon (assimilates) to the production of leaves that produced higher LWR and SLA (thinner leaves). This may have caused the plants grown in the low light environment to have a greater LAR, which is the photosynthetic surface area relative to plant weight, and as a result, the plant became capable of maintaining high RGR. Asmelash (2017) reported higher photosynthetic rates of $C$. indica at low light treatment, which supported the result of this experiment. In addition, increased investment in root and leaf structure in full sun-grown $C$. indica, slowed the growth rate by reducing the increase in leaf area, as reported in Parakmeria lotungensis (Magnoliaceae), a tropical shade tolerant species (Mao et al., 2014). Similar results of decreased NAR and increased SLA as light intensity decreases were reported in 14 plant species ( $\mathrm{Li}$ et al., 2016). These leaf traits characters found in this research are typical for plants to adapt to a low light environment, as it has been well documented for shade-tolerant plants (Wyka et al., 2012). However, for $C$. indica, this is the first reported study on the effect of light on leaf trait and growth characteristics. It seems that $C$. indica's strategy of building thin and efficient leaves in conditions of restricted light availability may be the explanation for its ecological success (Jagodziński et al., 2016).

Table 2. Correlations between relative growth rate, leaf traits, and biomass allocation of Canna indica.

\begin{tabular}{lllll}
\hline Light Treatment & LAR & LWR & SWR & R/S ratio \\
\cline { 2 - 6 } 25\% of natural light & -0.97 & 0.90 & -0.89 & 0.64 \\
50\% of natural light & -0.96 & -0.81 & -0.95 & 0.89 \\
Note: LAR=Lef natural light & -0.96 & -0.99 & -0.32 & 0.87 \\
\hline Leaf Area Ratio; LWR=Leaf Weight Ratio; SWR=Stem Weight Ratio
\end{tabular}


The reduction in leaf area and SLA in $C$. indica grew under full sun was probably also a response to high solar radiation, drought stress, and extreme temperatures (Azeñas et al., 2019; Leuschner \& Meier, 2018; Rosbakh et al., 2015). It was observed that on bright sunny days, the temperature was higher in full sun environment due to the direct sunlight at noon (data were not shown). This may have affected the soil of the full sun treatment and caused it to be drier than those in shaded treatments, especially compared to those grown under $25 \%$ light. It also explains the higher $\mathrm{R} / \mathrm{S}$ ratio in full sun-grown plants, which was an adaptation to drier soil by allocating more biomass to roots. This result was in accordance with significantly lower stomatal density on abaxial leaf surface of full sun-grown $C$. indica. Because abaxial surfaces specialize in gas exchange (Kidner \& Timmermans, 2010), a reduction in the number of stomata on this surface may function to reduce the amount of water loss, as reported in rice. Study shows that rice plants with fewer stomata are more drought-tolerant and water-efficient (Caine et al., 2019). On the other hand, $C$. indica grew under low light, produced higher stomatal density on adaxial surfaces, thus maximizing light captures. Significant effects of temperature fluctuation on growth were reported on long bean (Vigna sinensis), common bean (Phaseolus vulgaris), and winged bean (Psophocarpus tetragonolobus) (Sudiana et al., 2020).

Table 3. Plasticity indexes $( \pm \mathrm{SE})$ for morphological parameters of Canna indica grown under different light conditions.

\begin{tabular}{cc}
\hline Indexes & Plasticity Indexes \\
\hline Biomass allocation & $0.20 \pm 0.05$ \\
LWR & $0.30 \pm 0.08$ \\
SWR & $0.24 \pm 0.07$ \\
R/S ratio & 0.25 \\
Biomass allocation mean & \\
Leaf traits & $0.30 \pm 0.03$ \\
LAR & $0.15 \pm 0.04$ \\
SLA & 0.22 \\
Leaf traits mean & 0.23 \\
Phenotypic index &
\end{tabular}

Based on biomass allocation and plastic phenotypic response to light, we calculated that the phenotypic plasticity index for $C$. indica, was 0.23 (Table 3). Low phenotypic plasticity is typical for shade tolerant species (Gianoli \& Valladares, 2012; Mao et al., 2014). Shade-tolerant species have less light plasticity as part of a wider range of characteristics linked to resource protection and a high tolerance for low light stress. The plastic response of physiological and morphological variables of 16 tropical rain forest shrubs species from genus Psychotria (Rubiaceae) to three light treatments revealed that understory species (shade tolerant) showed less plasticity than gap species, indicating phenotypic stability rather than plasticity as a response to low light (Valladares et al., 2000). Similar results were reported by (Rozendaal et.al., (2006) who found that pioneer species had higher plasticity in the seedling stage compared to understory species.

This study revealed that $C$. indica can tolerate a variety of light growing conditions. When grown under a high light intensity (natural light), $C$. indica exhibited reduced SLA and adapted to this condition by producing thicker leaves and smaller leaf area that resulted in slower growth rate. This phenomenon is supported by its congeneric C. amabilis, C. discolor, and $C$. glauca, which are mostly planted as ornamental plants. These Canna species are capable of growing in open spaces with direct sunlight, and also under low light such as under shaded areas caused by structures such as bridges and buildings. These findings were the first time to be reported for $C$. indica. For agroforestry practices, it can be recommended that $C$. indica can be used as an intercropping plant under tree canopies, such as rubber plantations.

\section{CONCLUSION}

This study found that $25 \%$ natural light provides the best light growing condition for $C$. indica. All growth parameters observed were significantly higher than $C$. indica grown under $50 \%$ and $100 \%$ of natural light, respectively. The ability to adapt well to low light correlates with its low index of phenotypic plasticity. $C$ indica is a shade-tolerant species and can be used as an intercropping plant under tree canopies, such as under rubber or teak trees. Further research to see the effect of tree canopies on the growth of $C$. indica is recommended.

\section{ACKNOWLEDGEMENT}

We would like to thank the Indonesian Directorate General of Higher Education, the Ministry of National Education (SK: 01/E/KPT/2017) who provided funding for this research.

\section{REFERENCES}

Al-Snafi, A. E. (2015). Bioactive components and pharmacological effects of Canna indica - an overview. International Journal of Pharmacology \& Toxicology, 5(2): 71-75. 
Algar, A. F. C., Umali, A. B., \& Tabayong, R. R. P. (2019). Physicochemical and functional properties of starch from Philippine edible Canna (Canna indica L.) Rhizomes. Journal of Microbiology, Biotechnology and Food Sciences, 9(1), 34-37.

Andrade-Mahecha, M. M., Tapia-Blácido, D. R., \& Menegalli, F. C. (2012). Physical-chemical, thermal, and functional properties of achira (Canna indica L.) flour and starch from different geographical origins. Starch/Staerke, 64(5), 348358.

Asmelash, F. (2017). Two PhAR levels comparative photosynthetic gas exchange study on Canna indica and Morus alba grown in the Natural Sciences College of the Addis Two PhAR level comparative photosynthetic gas exchange study on Canna indica and Morus alba grown in the Natural [Technical Report. Addis Ababa University College of Natural Sciences Department of Plant Biology and Biodiversity Management].

Ayusman, S., Duraivadivel, P., Gowtham, H. G., Sharma, S., \& Hariprasad, P. (2020). Bioactive constituents, vitamin analysis, antioxidant capacity and $\alpha$-glucosidase inhibition of Canna indica L. rhizome extracts. Food Bioscience, 35, Article e100544.

Azeñas, V., Janner, I., Medrano, H., \& Gulías, J. (2019). Evaluating the establishment performance of six native perennial Mediterranean species for use in extensive green roofs under water-limiting conditions. Urban Forestry and Urban Greening, 41, 158-169.

BPS (Badan Pusat Statistik). (2017). Climate data of DKI Jakarta. https://jakarta.bps.go.id/

BPS (Badan Pusat Statistik). (2020). Impor Biji Gandum dan Meslin Menurut Negara Asal Utama, 2010-2019.

CABI (2020). CABI Compendium: Invasive species Wallingford, UK: Centre for Agriculture and Biosciences International. Canna indica (Canna lilly). https://www.cabi.org/isc/datasheet/14575.

Caine, R.S., Yin, X., Sloan, J., Harrison, E.L., Mohammed, U., Fulton, T., Biswal, A.K., Dionora, J., Chater, C.C., Coe, R.A., Bandyopadhyay, A., Murchie, E.H., Swarup, R., Quick, W.P. and Gray, J.E. (2019). Rice with reduced stomatal density conserves water and has improved drought tolerance under future climate conditions. New Phytologist, 221(1), 371-384.

Ciciarelli, M. de las M. (2012). Life Cycle in Natural Populations of Canna indica L. In Argentina. In $\mathrm{X}$. Zhang (Ed.), Phenology and Climate Change (1st Ed., pp. 101-116). InTech, Croatia.

Dwyer, J. M., Hobbs, R. J., \& Mayfield, M. M. (2014). Specific leaf area responses to environmental gradients through space and time. Ecology, 95(2), 399-410.

Ediviani, W., Priadi, C. R., \& Moersidik, S. S. (2018). Nutrient uptake from liquid digestate using ornamental aquatic macrophytes (Canna indica, Iris pseudacorus, Typha latifolia) in a constructed wetland system. Journal of Physics: Conference Series, 1022 (1).

Evans, J. R., \& Poorter, H. (2001). Photosynthetic acclimation of plants to growth irradiance: The relative importance of specific leaf area and nitrogen partitioning in maximizing carbon gain. Plant, Cell and Environment, 24(8), 755-767.

Gianoli, E., \& Valladares, F. (2012). Studying phenotypic plasticity: The advantages of a broad approach. Biological Journal of the Linnean Society, 105(1), 1-7.

Glinos, E., \& Cocucci, A. A. (2011). Pollination biology of Canna indica (Cannaceae) with particular reference to the functional morphology of the style. Plant Systematics and Evolution, 291, $49-58$.

Hunt, R. (1990). Basic growth analysis (First). Unwin Hyman Ltd.

Ifandari, Widyarini, S., Hartanto Nugroho, L., \& Pratiwi, R. (2020). Phytochemical analysis and cytotoxic activities of two distinct cultivars of ganyong rhizomes (Canna indica) against the widr colon cancer cell line. Biodiversitas, 21(4), 16601669.

Jagodziński, A. M., Dyderski, M. K., Rawlik, K., \& Katna, B. (2016). Seasonal variability of biomass, total leaf area and specific leaf area of forest understory herbs reflects their life strategies. Forest Ecology and Management, 374, 71-81.

Jiang, X., Song, X., Chen, Y., \& Zhang, W. (2014). Research on biogas production potential of aquatic plants. Renewable Energy, 69, 97-102.

Kidner, C. A., \& Timmermans, M. C. P. (2010). Signaling sides. Adaxial-abaxial patterning in leaves. Current Topics in Developmental Biology, 91(C), 141-168.

Leuschner, C., \& Meier, I. C. (2018). The ecology of Central European tree species: Trait spectra, functional trade-offs, and ecological classification of adult trees. Perspectives in Plant Ecology, Evolution and Systematics, 33, 89-103.

Li, X., Schmid, B., Wang, F., \& Paine, C. E. T. (2016). Net assimilation rate determines the growth rates of 14 species of subtropical forest trees. PLoS ONE, 11(3), 1-13.

Mao, P., Zang, R., Shao, H., \& Yu, J. (2014). Functional trait trade-offs for the tropical montane rain forest species responding to light from simulating experiments. Scientific World Journal, 2014 
McCarthy, M. C., \& Enquist, B. J. (2007). Consistency between an allometric approach and optimal partitioning theory in global patterns of plant biomass allocation. Functional Ecology, 21(4), 713-720.

Miao, M. Z., Liu, H. F., Kuang, Y. F., Zou, P., \& Liao, J. P. (2014). Floral vasculature and ontogeny in Canna indica. Nordic Journal of Botany, 32(4), 485-492.

Moossa, P. P., Thulasi, V., Raji, P., \& Prajesh, M. T. (2015). Exploration of plant biodiversity for nutrient harvesting. International Journal of Environmental and Agriculture Research, 1(8): 12-16.

Neufeld, H. S., \& Young, D. R. (2014). Ecophysiology of the Herbaceous Layer in Temperate Deciduous Forests. In F. S. Gilliam (Ed.), The herbaceous layer in forests of eastern North America (2nd Ed., pp. 35-112). Oxford University Press.

Okonwu, K., \& Ariaga, C. A. (2016). Nutritional evaluation of various parts of Canna indica $\mathrm{L}$. Annual Research and Review in Biology, 11(4), 15.

Pandey, S. K., \& Singh, H. (2011). A Simple, CostEffective Method for Leaf Area Estimation. Journal of Botany, 2011, 1-6.

Piyachomkwan, K., Chotineeranat, S., Kijkhunasatian, C., Tonwitowat, R., Prammanee, S., Oates, C. G., \& Sriroth, K. (2002). Edible canna (Canna edulis) as a complementary starch source to cassava for the starch industry. Industrial Crops and Products, 16(2002), 11-21.

Plant for a Future. (2020). Canna indica Indian Shot PFAF Plant Database. https://pfaf.org/user/ plant.aspx? latinname $=$ Canna + indica

Poorter, H., Niklas, K. J., Reich, P. B., Oleksyn, J., Poot, P., Mommer, L., ... Niklas, K. J. (2012). Biomass allocation to leaves, stems and roots: Meta-analyses of interspecific variation and environmental control. New Phytologist, 193(1), 30-50.

Rahajeng, W., Restuono, J., Indriani, F. C., \& Purwono, P. (2020). Genetic Parameters of Agronomic Traits in Sweetpotato Accessions. Biosaintifika: Journal of Biology \& Biology Education, 12(2), 240-246.

Rosbakh, S., Römermann, C., \& Poschlod, P. (2015). Specific leaf area correlates with temperature: new evidence of trait variation at the population, species and community levels. Alpine Botany, 125(2), 79-86.

Rozendaal, D. M. A., Hurtado, V. H., \& Poorter, L. (2006). Plasticity in leaf traits of 38 tropical tree species in response to light; relationships with light demand and adult stature. Functional Ecology, 20(2), 207-216.

Rudisirisak, K. (2019). Artificial Paper From Puttaraksa (Canna indica Linn) and Plubplueng (Crinum asiaticum). International Journal of GEOMATE, 16(55), 105-112.

Sari, N., Suryadiantina, Daryono, B. S., \& Purnomo. (2018). Variability and intraspecific classification of Indonesian edible canna (Canna indica L.) based on RAPD marker analysis. SABRAO Journal of Breeding and Genetics, 50(2): 156167.

Schulze, E.-D., Beck, E., Buchmann, N., Clemens, S., Müller-Hohenstein, K., \& Scherer-Lorenzen, M. (2019). Plant Ecology (Second). Springer-Verlag GmbH Germany, part of Springer Nature 2019.

Shipley, B. (2006). Net assimilation rate, specific leaf area and leaf mass ratio: Which is most closely correlated with relative growth rate? A metaanalysis. Functional Ecology, 20(4), 565-574.

Subhashini, V., \& Swamy, A. (2014). Phytoremediation of metal (PB, NI, ZN, CD, and CR) contaminated soils using Canna indica. Current World Environment, 9(3), 780-784.

Sudiana, E., Yani, E., Prayoga, L., Darsono, D., Riwidiharso, E., \& Santoso, S. (2020). Adaptations of three cash crops to climate change. Biosaintifika: Journal of Biology \& Biology Education, 12(2), 247-253.

Valladares, F., Sanchez-Gomez, D., \& Zavala, M. A. (2006). Quantitative estimation of phenotypic plasticity: Bridging the gap between the evolutionary concept and its ecological applications. Journal of Ecology, 94(6), 11031116.

Valladares, F., Wright, S. J., Lasso, E., Kitajima, K., \& Pearcy, R. W. (2000). Plastic phenotypic response to light of 16 congeneric shrubs from a Panamanian rainforest. Ecology, 81(7), 19251936.

Wafa, S. N., Mat Taha, R., Mohajer, S., Mahmad, N., \& Ahmed, A. B. A. (2016). Organogenesis and ultrastructural features of in vitro grown Canna indica L. BioMed Research International, 2016(2016), 9.

Wyka, T. P., Oleksyn, J., Żytkowiak, R., Karolewski, P., Jagodziński, A. M., \& Reich, P. B. (2012). Responses of leaf structure and photosynthetic properties to intra-canopy light gradients: A common garden test with four broadleaf deciduous angiosperm and seven evergreen conifer tree species. Oecologia, 170(1), 11-24.

Zhang, Z., Rengel, Z., \& Meney, K. (2008). Interactive effects of $\mathrm{N}$ and $\mathrm{P}$ on growth but not on resource allocation of Canna indica in wetland microcosms. Aquatic Botany, 89(3), 317-323. 
Yorianta Hidayat Sasaerila et al. / Biosaintifika 13 (2) (2021): 169-177 